\title{
Mixed Cryoglobulinaemia Vasculitis after Persistent Hepatitis C Virus Eradication
}

\author{
Margarida Gaudêncio ${ }^{1}$, Rui Nogueira², Nuno Afonso ${ }^{2,3}$ \\ ${ }^{1}$ Department of Internal Medicine, Hospital Distrital da Figueira da Foz, EPE, Figueira da Foz, Portugal \\ ${ }^{2}$ Department of Nephrology, Centro Hospitalar e Universitário de Coimbra, Coimbra, Portugal \\ ${ }^{3}$ Faculty of Medicine, University of Coimbra, Coimbra, Portugal
}

Received: 29/07/2021

Accepted: 01/08/2021

Published: $31 / 08 / 2021$

How to cite this article: Gaudêncio M, Nogueira R, Afonso N. Mixed cryoglobulinaemia vasculitis after persistent hepatitis C virus eradication. EJCRIM 2021;8: doi:10.12890/2021_002808.

Conflicts of Interests: The authors declare there are no competing interests.

This article is licensed under a Commons Attribution Non-Commercial 4.0 License

\section{ABSTRACT}

Mixed cryoglobulinaemia vasculitis (MCV) is a systemic vasculitis of the small and medium-size vessels caused by active hepatitis $\mathrm{C}$ (HCV) infection in $>80 \%$ of cases. Beuthien et al. presented the first case of MCV with undetectable HCV after 10 months of therapy. In the last few years, more authors have described other cases of symptomatic MCV after 1 year of persistent HCV eradication. Here, we present a case report of a 57-year-old man who developed MCV with renal involvement after 3 years of HCV eradication with interferon therapy.

\section{LEARNING POINTS}

- Mixed cryoglobulinaemia can occur after persistent hepatitis $C$ virus eradication.

- Most cases described in the literature presented mixed cryoglobulinaemia vasculitis (MCV) after 1 year of HCV eradication compared with after 3 years of persistent eradication in our case.

- The exact mechanism linking HCV and B-cells is not fully understood, but the main factor seems to be the sustained HCV antigenic stimulation of the B-cell compartment.

\section{KEYWORDS}

Mixed cryoglobulinemia, hepatitis $C$ virus, remission, vasculitis

\section{INTRODUCTION}

Cryoglobulinaemia is defined as the presence of cryoglobulins in serum ${ }^{[1]}$. According to Brouet's classification, there are three subtypes based on immunoglobulin composition ${ }^{[1]}$ : type I comprises single monoclonal immunoglobulins, while type II and type III are classified as mixed cryoglobulinaemia because they include two types of immunoglobulins ${ }^{[1]}$. Strictly speaking, the term cryoglobulinaemia is often used to refer to a systemic inflammatory syndrome that involves small-to-medium vessel vasculitis ${ }^{[1]}$. Hepatitis $\mathrm{C}$ virus (HCV) infection is a major public health problem, being one of the leading causes of end-stage liver disease and a major liver transplant indication ${ }^{[2]}$. It is also associated with a variety of extra-hepatic manifestations, such as mixed cryoglobulinaemia vasculitis (MCV), that may involve the skin, musculoskeletal system, kidneys and nervous system ${ }^{[1]}$. Renal manifestations range from isolated mild proteinuria with microscopic haematuria to an acute nephritic syndrome with renal insufficiency ${ }^{[3]}$. Membranoproliferative glomerulonephritis is the most common histological pattern seen on kidney biopsy ${ }^{[3,4]}$. A strong correlation has been shown between antiviral and vasculitic response ${ }^{[1,4]}$. However, there are some cases of persistence of MCV despite demonstration of effective HCV eradication ${ }^{[5]}$. The authors describe a case of new-onset MCV with renal involvement after 3 years of persistent HCV eradication. 


\section{CASE DESCRIPTION}

A 57-year-old man, a former drug addict, was diagnosed with active HCV genotype $1 \mathrm{~A}$ infection in 2013. He was successfully treated with pegylated-interferon (PEG-IFN) and ribavirin.

Three years later, the patient was referred for a nephrology consultation. His complaints were asthenia, anorexia, nausea, peripheral oedema, polyarthralgia, chronic pain and no skin lesions. Tests revealed acute renal failure (creatinine $418.6 \mathrm{mmol} / \mathrm{l}$ ), proteinuria and active urinary sediment (Table 1).

The patient was admitted to the nephrology department for further study which revealed anaemia (Hb 11.2 g/dl), hypocomplementaemia $\mathrm{C} 3 / \mathrm{CH} 50$, undetectable HCV RNA and positive cryoglobulins (Table 1). A kidney biopsy was performed and histology was compatible with sclerosing membranoproliferative glomerulonephritis with crescents and ischaemic tubulopathy lesions. Renal ultrasound showed kidneys with preserved morphology and dimensions, as well as parenchymal-sinusal differentiation.

\begin{tabular}{|c|c|c|c|}
\hline & At baseline & 2 Months after treatment & 2-Year follow-up \\
\hline Haemoglobin & - & - & $13.5 \mathrm{~g} / \mathrm{dl}$ \\
\hline Platelet count & $200,000 / \mu l$ & $250,000 / \mu l$ & $310,000 / \mu l$ \\
\hline Aminotransferase levels & Normal & Normal & Normal \\
\hline Coagulation & Normal & Normal & Normal \\
\hline Creatinine & $418.6 \mathrm{mmol} / \mathrm{l}$ & - & $115 \mathrm{mmol} / \mathrm{l}$ \\
\hline Proteinuria & $10 \mathrm{~g} / \mathrm{l}$ & - & - \\
\hline Urinary protein/creatinine ratio & $16.7 \mathrm{~g} / \mathrm{g}$ & $9.4 \mathrm{~g} / \mathrm{g}$ & $0.76 \mathrm{~g} / \mathrm{g}$ \\
\hline HCV viral load & Undetectable & Undetectable & Undetectable \\
\hline Other infections (syphilis, HIV, HBV) & Negative & - & - \\
\hline ANA, anti-DNA ds, ANCA, GBM & Negative & - & - \\
\hline $\lg , \lg A$ and $\lg M$ & Without monoclonal expression & - & - \\
\hline C3 & $0.46 \mathrm{~g} / \mathrm{l}(0.9-1.8)$ & - & $1 \mathrm{~g} / \mathrm{l}(0.9-1.8)$ \\
\hline C4 & $0.2 \mathrm{~g} / \mathrm{l}(0.1-0.4)$ & - & $0.3 \mathrm{~g} / \mathrm{l}(0.1-0.4)$ \\
\hline $\mathrm{CH} 50$ & $20 \mathrm{U} / \mathrm{ml}(31.6-57.6)$ & - & $40 \mathrm{U} / \mathrm{ml}(31.6-57.6)$ \\
\hline Cryoglobulinaemia & Detectable & Undetectable & Undetectable \\
\hline
\end{tabular}

Table 1. Patient data at baseline and during follow-up

ANA, antinuclear antibodies; ANCA, antineutrophil cytoplasmic antibodies; Anti-DNA ds, anti-double stranded DNA antibodies; GBM, glomerular basement membrane antibodies; HBV, hepatitis B virus; $H C V$, hepatitis $C$ virus; HIV, human immunodeficiency virus. 
The patient was treated with methylprednisolone pulse therapy $(1 \mathrm{~g} / \mathrm{day}$ for 3 consecutive days), followed by prednisone $1 \mathrm{mg} / \mathrm{kg} / \mathrm{day}$. After 1 week of treatment, a response was obtained with a reduction in urinary protein excretion and partial recovery of renal function (Table 1). Two months later, the patient's renal function had markedly improved and so azathioprine $1.5-2.5 \mathrm{mg} / \mathrm{kg} / \mathrm{day}$ was introduced and prednisone was reduced to $10 \mathrm{mg}$ per week. Two years later, the patient still had undetectable HCV RNA replication and also showed no MCV manifestations or cryoglobulins (Table 1). Consequently, he maintained prednisone $2.5 \mathrm{mg} / \mathrm{day}$ but stopped azathioprine. Currently, he has coexisting illness, including hypertension and dyslipidaemia.

During treatment, alternative conditions that could predispose to MCV were excluded, namely, autoimmune diseases, other infectious diseases and malignant lymphoproliferative disease.

\section{DISCUSSION}

Mixed cryoglobulinaemia vasculitis (MCV) is a systemic vasculitis of the small and medium-size vessels caused by active hepatitis C (HCV) infection in $>80 \%$ of cases ${ }^{[1]}$. The fundamental mechanism contributing to this disease is aberrant autoantibody production by B-cells and B-cell proliferation ${ }^{[1]}$. Several underlying diseases can facilitate this by interfering with normal B-cell function ${ }^{[1]}$. Hepatitis $C$ virus (HCV) infection is the most common cause of $\mathrm{MC}^{[1]}$. Treatment of MCV generally consisted of glucocorticoids, cytotoxic agents and plasmapheresis ${ }^{[1]}$. Targeted therapy with antiviral treatment such as interferon alpha (IFNa) or with PEG-INF plus ribavirin provided a new treatment for HCV infection and MCV, and have been proven to be much more successful at achieving remission ${ }^{[1]}$.

The authors have described a very unusual case of mixed cryoglobulaemia with renal involvement after long-term successful HCV eradication, without any evidence of underlying disease. The first report of MCV onset after interferon therapy was presented by Beuthien et al. ${ }^{[6]}$. In this case, MCV was diagnosed 10 months after the beginning of PEG-INF treatment; at that time, HCV RNA was undetectable, however, the patient was undergoing INF therapy, which was not provided in our case ${ }^{[5,6]}$. Other authors described cases of symptomatic cryoglobulinaemia after sustained HCV eradication with antiviral therapy ${ }^{[7]}$. Those patients experienced an MCV relapse during the first year after therapy ${ }^{[7]}$. Finally, Quartuccio et al. and Silva et al. reported two cases quite similar to ours, of new onset MCV 3 and 4 years after persistent HCV eradication ${ }^{[8,9]}$. There are still no pathophysiological data to explain these events. However, all these cases suggest a relationship between HCV and B-cells, namely, sustained antigen stimulation of B-cells ${ }^{[10,11]}$. This relationship underlies the more recent use of rituximab in cases of severe and refractory disease ${ }^{[1]}$. However, we did not use rituximab in our patient given the good response to corticosteroid therapy.

In conclusion, with this case, the authors emphasize the possibility of HCV-related MCV and its renal manifestations, in patients with longstanding HCV virus eradication.

\section{REFERENCES}

1. Roccatello D, Saadoun D, Ramos-Casals M, Tzioufas AG, Fervenza FC, Cacoub P, et al. Cryoglobulinaemia. Nat Rev Dis Primers 2018;4(1):11.

2. Lauer G, Walker BD. Hepatitis C virus infection. N Engl J Med 2001;345(1):41-52.

Pol S, Parlati L, Jadoul M. Hepatitis C virus and the kidney. Nat Rev Nephrol 2019;15:73-86.

Dammaco F, Sansonno D. Therapy for hepatitis C virus-related cryoglobulinemic vasculitis. N Engl J Med 2013;369:1035-1045.

Boonyapisit K, Katiriji B. Severe exacerbation of hepatitis C-associated vasculitic neuropathy following treatment with interferon alpha: a case report and literature review. Muscle Nerve 2002;25(6):909-913.

6. Beauthien W, Mellinghoff H-U, von Kempis J. Vasculitic complications of interferon-alpha treatment for chronic hepatitis $\mathrm{C}$ infection: case report and review of literature. Clin Rheumatol 2005;24(5):507-515.

7. Kartha V, Franco L, Coventry S, McLeish K, Caster DJ, Schadt CR. Hepatitis C mixed cryoglobulinemia with undetectable viral load: a case series. JAAD Case Rep 2018;4:684687.

8. Quartuccio L, De Marchi G, Fabris M, De Vita S. Development of type II cryoglobulinaemic syndrome after effective and persistent hepatitis C virus eradication. Rheumatology 2007:46(2):367-368.

9. Silva RF, Malvar B, Santos R, Pessegueiro P, Aniceto J, Ramalho V, et al. New onset of mixed cryoglobulinemia vasculitis after persistent hepatitis C virus eradication. Port J Nephrol Hypert 2013;27(4):289-294.

10. De Re V, Sansonno D, Simula MP, Caggiari L, Gasparotto D, Fabris M, et al. HCV-NS3 and IgG-Fc crossreative IgM in patients with type II mixed cryoglobulinemia and B-cel clonal proliferation. Leukemia 2006;20(6):1145-1154.

11. Rosa D, Saletti G, De Gregorio E, Zorat F, Comar C, D'Oro U, et al. Activation of naive B lymphocytes via CD81, a pathogenic mechanism for hepatitis C virus associated B lymphocyte disorders. Proc Natl Acad Sci U S A 2005;102(51):18544-18549. 